Article

\title{
The Effect of the Dose of Isotonic Saline on the Correction of Serum Sodium in the Treatment of Hypovolemic Hyponatremia
}

\author{
Jorge Gabriel Ruiz-Sánchez ${ }^{1, *(\mathbb{D}}$, Diego Meneses ${ }^{2}{ }^{(0)}$, Cristina Álvarez-Escolá ${ }^{3}$, Martin Cuesta ${ }^{1,4}$, \\ Alfonso Luis Calle-Pascual ${ }^{1,4}$ (D) and Isabelle Runkle ${ }^{1}$ (D) \\ 1 Servicio de Endocrinología y Nutrición, Hospital Clínico San Carlos, Instituto de Investigación Sanitaria del \\ Hospital Clínico San Carlos (IdISSC), 28040 Madrid, Spain; cuestamartintutor@gmail.com (M.C.); \\ acallepascual@hotmail.com (A.L.C.-P.); irunkledelavega@gmail.com (I.R.) \\ 2 Departamento de Endocrinología, Hospital Universitario Fundación Jiménez Díaz, 28040 Madrid, Spain; \\ samoth67@gmail.com \\ 3 Servicio de Endocrinología y Nutrición, Hospital Universitario La Paz, 28046 Madrid, Spain; \\ escola.cristina@gmail.com \\ 4 Centro de Investigación Biomédica en Red de Diabetes y Enfermedades Metabólicas \\ Asociadas (CIBERDEM), 28029 Madrid, Spain \\ * Correspondence: gajo_saru@hotmail.com
}

Received: 17 September 2020; Accepted: 3 November 2020; Published: 5 November 2020

\begin{abstract}
Background: Overcorrection of serum sodium (SNa) during therapy of hyponatremia can result in osmotic demyelination syndrome. Our aim was to determine the relationship between the isotonic saline solution dose (ISSD) administered and the 24-h SNa increase (24SNa) in patients with hypovolemic hyponatremia (HH). Methods: Retrospective study of $\mathrm{HH}$ patients treated with ISS in a tertiary hospital of Madrid, Spain, between 1 January-30 May 2019. The 24-h ISSD received and corresponding $24 \mathrm{SNa}$ were calculated. The latter was classified as 3 groups: $\geq 8 \mathrm{mmol} / \mathrm{L}, \geq 6 \mathrm{mmol} / \mathrm{L}$, or $<4 \mathrm{mmol} / \mathrm{L}$. Multivariate regression analyses were performed and ROC curves calculated to study the relationship between ISSD and 24SNa. Results: Thirty patients were included, age 72 years (60-80), $50 \%$ were women. $24 \mathrm{SNa}$ was $\geq 8 \mathrm{mmol} / \mathrm{L} / 24 \mathrm{~h}$ in $33 \%, \geq 6 \mathrm{mmol} / \mathrm{L} / 24 \mathrm{~h}$ in $50 \%$, and $<4 \mathrm{mmol} / \mathrm{L} / 24 \mathrm{~h}$ in $30 \%$. Median ISSD in each group was: $32 \mathrm{~mL} / \mathrm{kg} / 24 \mathrm{~h}(29-37), 31 \mathrm{~mL} / \mathrm{kg} / 24 \mathrm{~h}(25-33)$, and $20 \mathrm{~mL} / \mathrm{kg} / 24 \mathrm{~h}$ (14-22), respectively. An ISSD $\geq 30 \mathrm{~mL} / \mathrm{kg} / 24 \mathrm{~h}$ had an odds ratio (OR) of 16 (95\% CI: 2.5-95.1; $p=0.004$ ) for a $24 \mathrm{SNa} \geq 8 \mathrm{mmol} / \mathrm{L}$, with a sensitivity and specificity of $80 \%$. Conclusions: The $24 \mathrm{SNa}$ depends on ISSD. An ISSD between $23-30 \mathrm{~mL} / \mathrm{kg} / 24 \mathrm{~h}$ seems to be safe and effective.
\end{abstract}

Keywords: hyponatremia; hypovolemic hyponatremia; hyponatremia treatment; overcorrection; isotonic saline; physiological saline

\section{Introduction}

Hyponatremia is the most frequently encountered electrolyte disorder in clinical practice [1-3]. Patients with hypovolemic hyponatremia $(\mathrm{HH})$ are characterized by a reduction in total body water. Effective circulating volume (ECV) is reduced, inducing non-osmotic stimulation of arginine vasopressin (AVP) secretion via baroreceptors [1]. In fact, reductions of ECV as low as $5 \%$ stimulate AVP secretion [4], inducing antidiuresis. The stimulus is acute, and hypotension in experimental animals can result in the liberation of AVP from the neurohypophysis within 1 min [5,6]. Conversely, the correction of hypovolemia will rapidly inhibit AVP secretion [4], reestablishing diuresis and increasing serum sodium $(\mathrm{SNa})$. 
Mild/moderate HH is usually treated with IV infusion of an isotonic saline solution (ISS) [1,2]. ISSs are crystalloid solutions containing from 131 to $154 \mathrm{mmol} / \mathrm{L}$ of sodium [7,8]. This therapy has often been associated with marked increases in SNa during the first 24 and/or $48 \mathrm{~h}$ of infusion $[1,2,9,10]$. High SNa increments have been found to facilitate the development of osmotic demyelination syndrome (ODS), a condition with an elevated morbidity and mortality. Patients with chronic hyponatremia, lasting a minimum of $48 \mathrm{~h}$, are at particularly high risk for the development of ODS when presenting risk factors such as alcoholism, liver disease, hypokalemia, and/or malnutrition [11-14]. Although the goal in the treatment of patients with chronic hyponatremia is a $24-\mathrm{h} \mathrm{SNa}$ rise of 4-6 $\mathrm{mmol} / \mathrm{L}[1,2]$, guidelines have defined overcorrection of hyponatremia as a 24 -h elevation of $\mathrm{SNa}(24 \mathrm{SNa})>10 \mathrm{mmol} / \mathrm{L}$ [1] or $>10-12 \mathrm{mmol} / \mathrm{L}$ [2] in patients with chronic hyponatremia, or over $8 \mathrm{mmol} / \mathrm{L}$ in patients at a high risk for ODS. SNa increments higher than $18 \mathrm{mmol} / \mathrm{L}$ in $48 \mathrm{~h}$ after initiation of therapy are also defined as overcorrection. In patients with risk factors for ODS, SNa should not increase by more than $8 \mathrm{mmol} / \mathrm{L}$ in each 24-h period during the first $48 \mathrm{~h}$ [2].

The relationship between the dose of ISS (ISSD) used to treat $\mathrm{HH}$ and the risk for overcorrection of SNa has yet to be elucidated. For this reason, our goal was to evaluate the relationship between the ISSD administered and the 24-h SNa response in a group of patients with $\mathrm{HH}$, in an attempt to ascertain what would constitute a "safe" and effective dose.

\section{Experimental Section}

The current study is a retrospective analysis of a consecutive series of patients over 18 years of age, with $\mathrm{HH}$, treated by clinicians of the endocrinology department of La Paz, a tertiary hospital in Madrid, Spain. Therapy consisted of IV infusion of ISS ( $\mathrm{NaCl} 0.9 \%$, or a balanced isotonic crystalloid solution of $\mathrm{NaCl} 0.81 \%$ ) for the correction of $\mathrm{HH}$. Treatment was initiated either in the emergency room, or on the wards. Patients were followed up daily for a minimum of two consecutive days. The patients were treated between January 1st and May 30th of 2019.

Patients were diagnosed with $\mathrm{HH}$ on the basis of (1) SNa $<135 \mathrm{mmol} / \mathrm{L}$ (after correction for glycemia) [15], (2) maximum height of the internal jugular pulse (HIJP) less than $1 \mathrm{~cm}$ over the sternal angle with the patient reclined at $0-30^{\circ}$ [16], and (3) at least two of the following: thirst, orthostatic symptoms, hypotension (blood pressure $\leq 90 / 60 \mathrm{mmHg}$ ), tachycardia (heart rate $\geq 90 \mathrm{bpm}$ ), urinary sodium (US) $\leq 30 \mathrm{mmol} / \mathrm{L}[17,18]$, or a rise in serum creatinine/urea accompanying the descent in SNa $[19,20]$. When the HIJP was not measured, HH was diagnosed with the presence of at least three of the other clinical features previously described above. All HH patients with serum biochemical parameters measured exactly $24 \mathrm{~h}$ after ISS infusion were included. No patient with a prior history of heart failure or a clinical history or physical examination compatible with heart failure was included.

Serum electrolytes were measured by indirect electrode methodology. Blood and urine samples were collected for biochemical analysis at baseline, as well as $24 \mathrm{~h}$ after the initiation of ISS therapy. Baseline variables evaluated were: age, sex, recent weight, $\mathrm{SNa}$ (with a SNa $\leq 120 \mathrm{mmol} / \mathrm{L}$ considered severe hyponatremia), serum potassium (SK), serum creatinine, serum urea, serum glycemia, the duration of hyponatremia prior to initiation of therapy (classified as acute hyponatremia if $<48 \mathrm{~h}$, and chronic if $\geq 48 \mathrm{~h}$ ), risk factors for the development of ODS (SNa $<105 \mathrm{mmol} / \mathrm{L}$, malnutrition, hypokalemia, alcoholism, liver disease), and the setting in which therapy was initiated (emergency room, medical or surgical ward).

Data collected $24 \mathrm{~h}$ following initiation of ISS therapy were: ISSD administered IV in $\mathrm{mL} / \mathrm{kg}$ body weight $/ 24 \mathrm{~h}, \mathrm{SNa}$, SK, serum creatinine, serum urea, glycemia, etiology of hypovolemia (gastrointestinal losses-vomiting and/or diarrhea, urinary losses—diuretic therapy or US $>30 \mathrm{mmol} / \mathrm{L}-$, hemorrhage, or indeterminate if the prior causes were not present), type of ISS infused ( $\mathrm{NaCl} 0.9 \%$ (containing $154 \mathrm{mmol} / \mathrm{L}$ of $\mathrm{Na}^{+}$) or balanced crystalloid $\mathrm{NaCl} 0.81 \%$ (containing $140 \mathrm{mmol} / \mathrm{L}$ of Na${ }^{+}$), both considered isotonic solutions $[7,8])$, oral or IV therapy with potassium chloride $(\mathrm{KCl})$. 
The main variable studied was the $24 \mathrm{SNa}$ increment following initiation of ISS. Patients were classified as a function of the $24 \mathrm{SNa}$ rise as follows: $\geq 8 \mathrm{mmol} / \mathrm{L}(\Delta \geq 8), \geq 6 \mathrm{mmol} / \mathrm{L}(\Delta \geq 6)$, or $<4 \mathrm{mmol} / \mathrm{L}(\Delta<4)$. The limits used were chosen based on guideline goals for SNa correction in chronic hyponatremia $[2,21,22]$, as well as the upper limit in patients with risk factors for ODS. Insufficient therapy or undertreatment was defined as a $24 \mathrm{SNa}$ increment below $4 \mathrm{mmol} / \mathrm{L}(\Delta<4)$.

The descriptive analysis of the categorical variables was carried out with frequencies and percentages, and that of the quantitative variables with measures of central tendency. Non-parametric variables expressed as the median (interquartile range: IQR) were used. Comparative analysis of the quantitative variables was performed using Mann-Whitney U or Kruskal-Wallis tests. The chi-squared test and the Fisher test were used for qualitative variables. Boxplot graphics were used to show comparative results of quantitative variables. The ends of the whiskers of the boxplots represent the minimum and maximum of all data. The bottom and top of the box represent the 25th and 75th percentile respectively, and the band near the middle of the box, the 50th percentile.

To establish the relationship between 24SNa increments and ISSD, Receiver Operating Characteristic ROC curves were used, calculating the area under the curve (AUC). Different cut-off points of ISSD linked to the SNa increase were obtained. Sensitivity (SS), specificity (SP), positive predictive value (PPV) and negative predictive value (NPV) were then calculated from the cut-off points selected by the researchers. Multivariate and univariate logistic regression analysis was performed and odd ratios (OR) were calculated to complement the association study between the ISSD and the 24SNa increase. The multivariable model included factors shown as statistically significant in the univariate analysis. A two-tailed $p$ value $<0.05$ was considered to be statistically significant. Ninety-five percent confidence intervals $(95 \% \mathrm{CI})$ were calculated when applicable. Statistical analysis was performed using SPSS version 25 (IBM Corp., Armonk, NY, USA).

The study complied with accepted standards of good clinical practice, according to the Helsinki declaration. The research guidelines of the local committee were met and were known by all authors. The study did not require informed consent, given its retrospective nature.

\section{Results}

A total of 30 cases of patients with $\mathrm{HH}$ were analyzed. The median age of patients was 72 years (60-80), 15 (50\%) were women. A majority of patients (23/30: $77 \%)$ had at least one risk factor for the development of ODS. The median pre-treatment SNa was $128 \mathrm{mmol} / \mathrm{L}(125-130)$. Thirteen $(43 \%)$ patients had been receiving diuretics before hyponatremia was diagnosed. Eleven patients (37\%) had a history of treatment with at least one of the following drugs: an angiotensin-converting enzyme inhibitor, an angiotensin-receptor blocker, or a mineralocorticoid-receptor antagonist. Thirteen patients $(43 \%)$ had signs of infection coinciding with the hyponatremic episode. Nine patients presented with a gastrointestinal infection, two with pneumonia, and two with sepsis of unknown origin. In all patients, serum glycemia was consistently below $150 \mathrm{mg} / \mathrm{dL}$, and correction of SNa for glycemia was not required. Other baseline patient characteristics are described in Table 1. 
Table 1. Characteristics of the patients of the study.

\begin{tabular}{|c|c|}
\hline \multicolumn{2}{|l|}{$N=30(100 \%)$} \\
\hline Age, years & $72(60-80)$ \\
\hline Sex female, $n(\%)$ & $15(50 \%)$ \\
\hline \multicolumn{2}{|c|}{ Clinical markers of hypovolemia } \\
\hline Blood pressure $\leq 90 / 60 \mathrm{mmHg}, n(\%)$ & $7(23 \%)$ \\
\hline Heart rate $\geq 90 \mathrm{bpm}, n(\%)$ & $12(40 \%)$ \\
\hline Decreased internal jugular vein pulse height $(n=22), n(\%)$ & $22(100 \%)$ \\
\hline Orthostatic symptoms $(n=20), n(\%)$ & $14(70 \%)$ \\
\hline \multicolumn{2}{|c|}{ Biochemical serum parameters } \\
\hline Sodium mmol/L & $128(125-130)$ \\
\hline Potassium mmol/L & $4(3.4-4.5)$ \\
\hline Creatinine mg/dL & $0.98(0.55-1.61)$ \\
\hline Urea mg/dL & $43(27.7-75)$ \\
\hline Risk Factors for Osmotic demyelination syndrome, $n(\%)$ & $23(78 \%)$ \\
\hline Malnutrition, $n(\%)$ & $18(60 \%)$ \\
\hline Hypokalemia, $n(\%)$ & $9(30 \%)$ \\
\hline Alcoholism, $n(\%)$ & $2(7 \%)$ \\
\hline Liver disease, $n(\%)$ & $1(3 \%)$ \\
\hline \multicolumn{2}{|l|}{ Location of the patients } \\
\hline Emergency room, $n(\%)$ & $16(53 \%)$ \\
\hline Hospitalization ward, $n(\%)$ & $14(47 \%)$ \\
\hline \multicolumn{2}{|l|}{ Type of isotonic saline solution } \\
\hline $\mathrm{NaCl} 0.9 \%, n(\%)$ & $25(83 \%)$ \\
\hline $\mathrm{NaCl} 0.81 \%, n(\%)$ & $5(17 \%)$ \\
\hline \multicolumn{2}{|l|}{ Etiology of hypovolemia } \\
\hline Unknown, $n(\%)$ & $8(27 \%)$ \\
\hline Gastrointestinal losses, $n(\%)$ & $13(43 \%)$ \\
\hline Urinary losses, $n(\%)$ & $17(57 \%)$ \\
\hline Blood loss $n(\%)$ & $2(7 \%)$ \\
\hline
\end{tabular}

Quantitative variables are given as median and (interquartile range).

The median ISSD administered was $25 \mathrm{~mL} / \mathrm{kg} / 24 \mathrm{~h}$ (21-33). The 24-h levels of biochemical parameters after ISS administration were as follows: $132 \mathrm{mmol} / \mathrm{L}(130-136)$ for SNa, $3.8 \mathrm{mmol} / \mathrm{L}$ (3.5-4.1) for SK, $0.9 \mathrm{mg} / \mathrm{dL}$ (0.65-1.37) for serum creatinine, and $42 \mathrm{mg} / \mathrm{dL}$ (29.5-70) for serum urea. Comparative evolution of these parameters at $24 \mathrm{~h}$ are illustrated in Figure 1.

In $10(33 \%)$ patients, the $24 S N a$ showed a $\Delta \geq 8 \mathrm{mmol} / \mathrm{L}$ after a median ISSD of $32 \mathrm{~mL} / \mathrm{kg} / 24 \mathrm{~h}(29-37)$. In $15(50 \%)$ patients, the $24 \mathrm{SNa}$ exhibited a $\Delta \geq 6 \mathrm{mmol} / \mathrm{L}$ after a median ISSD of $31 \mathrm{~mL} / \mathrm{kg} / 24 \mathrm{~h}(25-33)$. In $11(48 \%)$ of the 23 patients with at least one risk factor for ODS, the $24 S N a$ showed a $\Delta \geq 6 \mathrm{mmol} / \mathrm{L}$, following a median ISSD of $31 \mathrm{~mL} / \mathrm{kg} / 24 \mathrm{~h}(23-37)$.

The $24 \mathrm{SNa}$ had a $\Delta<4 \mathrm{mmol} / \mathrm{L}$ in nine patients $(30 \%)$, following the administration of a median ISSD of $20 \mathrm{~mL} / \mathrm{kg} / 24 \mathrm{~h}$ (14-22). In eight of these nine patients, the administered dose was $\leq 23 \mathrm{~mL} / \mathrm{kg} / 24 \mathrm{~h}$.

Patients receiving a larger volume of ISS had a higher 24SNa increment (Figure 2). There was a positive correlation between the ISSD and the 24SNa rise (Pearson correlation coefficient of +0.65 , $p=0.001)$. 

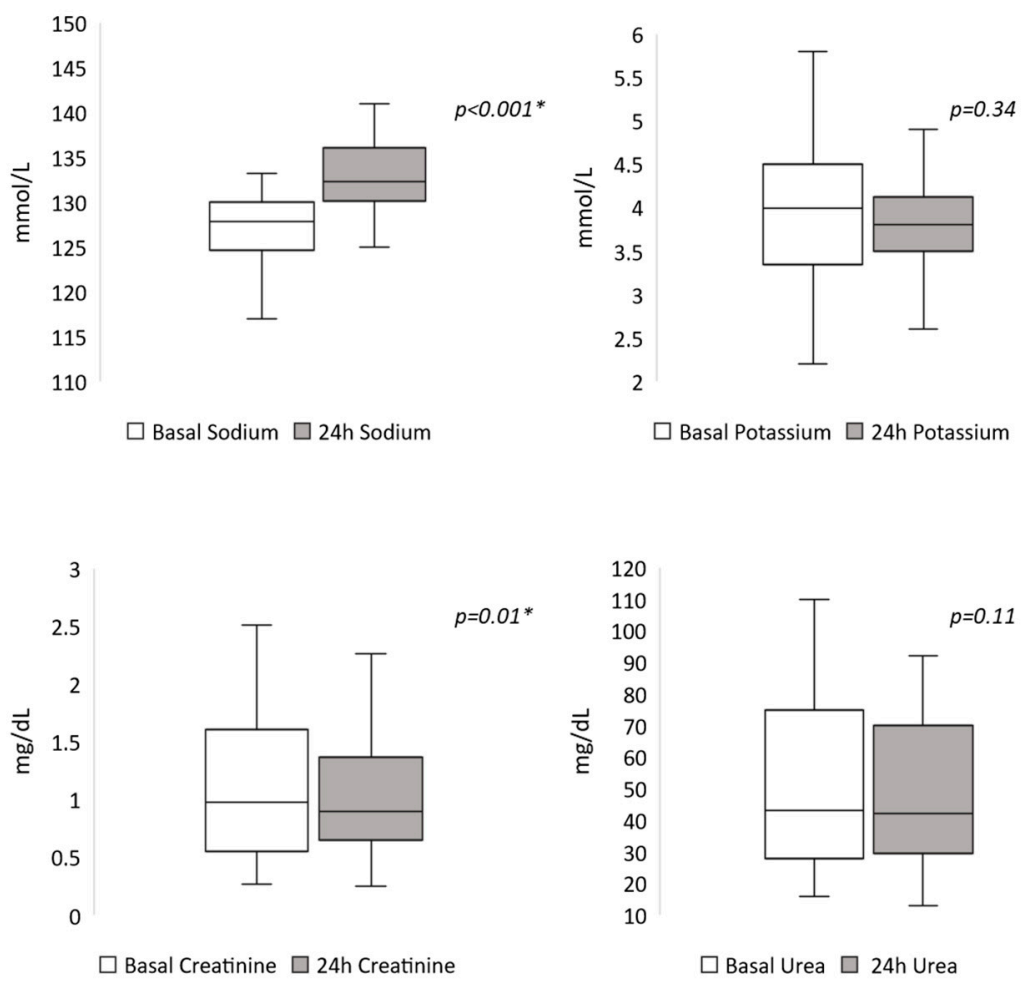

Figure 1. Evolution of serum biochemical parameters after $24 \mathrm{~h}$ of isotonic saline solution administration. ${ }^{*} p<0.05$.

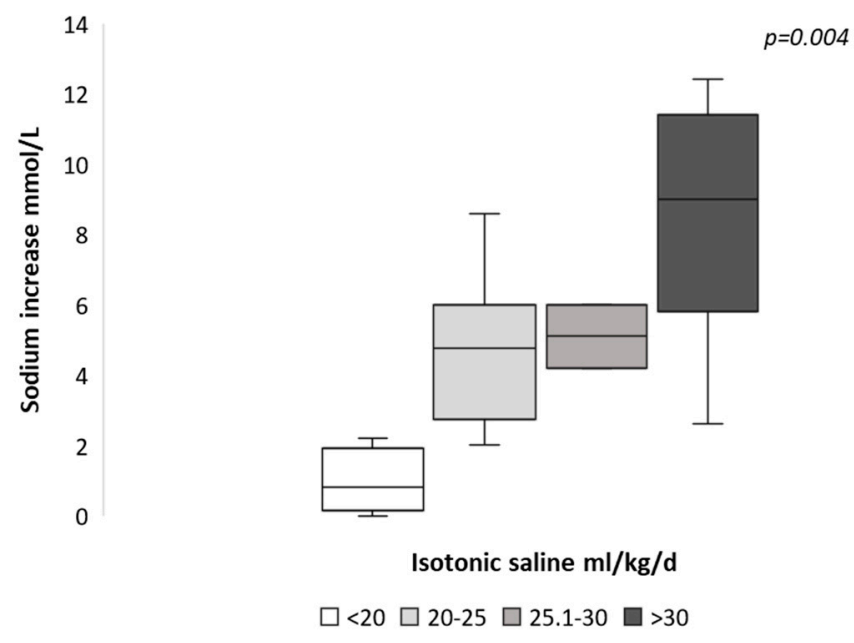

Figure 2. Median 24-h serum sodium (SNa) increments according to isotonic saline solution doses.

Excluding ISSD, the baseline SNa level was the only variable found to be associated with the 24-h SNa increase, and was lower in patients exhibiting a 24SNa $\Delta \geq 8 \mathrm{mmol} / \mathrm{L}$ (median $125 \mathrm{mmol} / \mathrm{L}$ (122-127)) as compared to those who did not (median $129 \mathrm{mmol} / \mathrm{L}(127-131), p=0.044)$. The remaining univariate analyses performed for the entire group of patients are shown in Table 2. 
Table 2. Comparative analysis of the clinical variables studied as function of 24-h SNa increase.

\begin{tabular}{|c|c|c|c|c|c|c|}
\hline & \multicolumn{3}{|c|}{ 24-h SNa $\Delta \geq 8 \mathrm{mmol} / \mathrm{L}$} & \multicolumn{3}{|c|}{ 24-h SNa $\Delta \geq 6 \mathrm{mmol} / \mathrm{L}$} \\
\hline & Yes $(n=10)$ & No $(n=20)$ & $p^{*}$ & Yes $(n=15)$ & No $(n=15)$ & $p^{*}$ \\
\hline Female, \% & 70 & 40 & \multirow{2}{*}{0.12} & 67 & 33 & \multirow{2}{*}{0.68} \\
\hline Male, $\%$ & 30 & 60 & & 33 & 67 & \\
\hline Age, years & $72(47-84)$ & $75(60-79)$ & 0.681 & $72(51-83)$ & $72(60-77)$ & 0.967 \\
\hline Weight, kg & $53(49-61)$ & $61(53-72)$ & 0.067 & $58(49-65)$ & $58(53-72)$ & 0.187 \\
\hline $\begin{array}{c}\text { Basal serum sodium, } \\
\mathrm{mmol} / \mathrm{L}\end{array}$ & $\begin{array}{c}125 \\
(122-127)\end{array}$ & $\begin{array}{c}129 \\
(127-131)\end{array}$ & 0.044 * & $\begin{array}{c}125 \\
(122-131)\end{array}$ & $\begin{array}{c}129 \\
(127-130)\end{array}$ & 0.067 \\
\hline $\begin{array}{c}\text { Basal serum sodium } \leq \\
120 \mathrm{mmol} / \mathrm{L}, \%\end{array}$ & 10 & 10 & 1 & 13.3 & 6.7 & 1 \\
\hline $\begin{array}{c}\text { Risk factors for } \\
\text { osmotic demyelination } \\
\text { syndrome, \% }\end{array}$ & 80 & 75 & 0.76 & 73.3 & 80 & 0.66 \\
\hline Malnutrition, $\%$ & 60 & 60 & 1 & 53 & 67 & 0.45 \\
\hline Hypokalemia, \% & 30 & 30 & 1 & 27 & 34 & 1 \\
\hline Alcoholism, \% & 0 & 10 & 0.3 & 0 & 13 & 0.14 \\
\hline Liver disease, $\%$ & 0 & 5 & 0.47 & 0 & 7 & 0.3 \\
\hline $\begin{array}{c}\text { Duration of } \\
\text { hyponatremia } \\
\text { Acute, \% } \\
\text { Chronic, \% } \\
\end{array}$ & \multicolumn{5}{|c|}{$\begin{array}{c}\text { Duration of } \\
\text { hyponatremia }\end{array}$} & 0.169 \\
\hline $\begin{array}{l}\text { Location of patients } \\
\text { Emergency room, \% } \\
\text { Hospitalization ward, \% }\end{array}$ & $\begin{array}{l}50 \\
50\end{array}$ & $\begin{array}{l}45 \\
55\end{array}$ & 1 & $\begin{array}{l}60 \\
40\end{array}$ & $\begin{array}{l}33 \\
67\end{array}$ & 0.272 \\
\hline $\begin{array}{c}\text { Associated potassium } \\
\text { chloride treatment, \% } \\
\text { Type of isotonic saline } \\
\text { solution } \\
\mathrm{NaCl} 0.9 \%, \% \\
\mathrm{NaCl} 0.81 \%, \%\end{array}$ & $\begin{array}{l}90 \\
10\end{array}$ & $\begin{array}{l}80 \\
20\end{array}$ & 0.64 & $\begin{array}{c}93 \\
7\end{array}$ & $\begin{array}{l}73 \\
27\end{array}$ & 0.33 \\
\hline $\begin{array}{c}\text { Isotonic saline } \\
\text { solution dose, } \\
\mathrm{mL} / \mathrm{kg} / 24 \mathrm{~h}\end{array}$ & $32(29-37)$ & $23(20-30)$ & 0.005 * & $31(25-33)$ & $21(17-29)$ & $0.006^{*}$ \\
\hline
\end{tabular}

Quantitative variables are given as median and (interquartile range). ${ }^{*} p<0.05$. SNa $\Delta$ : variation in serum sodium.

Univariate logistic regression analysis revealed that for each $\mathrm{mL} / \mathrm{kg} / 24 \mathrm{~h}$ of ISS administered, the OR for a 24SNa $\Delta \geq 8$ was 1.19 (95\% CI: $1.036-1.368, p=0.014$ ), and of 1.16 (95\% CI: 1.026-1.312, $p=0.018$ ) for a $24 \mathrm{SNa} \Delta \geq 6$ in the entire group of patients. In those with ODS risk factors, the OR for a $24 \mathrm{SNa} \Delta \geq 6$ was 1.13 (95\% CI: $1.007-1.278, p=0.038$ ).

In the entire group of patients, the AUC of ISSD in the ROC curve was 0.815 (95\% CI: $0.661-0.969$, $p=0.006$ ) for a 24 SNa $\Delta \geq 8$ and of 0.791 (95\% CI: $0.616-0.966, p=0.007)$ for a 24 SNa $\Delta \geq 6$. In the group of patients with ODS risk, the AUC of ISSD was 0.788 (95\% CI: 0.588-0.988, $p=0.019$ ) for a $24 \mathrm{SNa} \Delta \geq 6$. Table 3 shows the cut-off points selected for SS, SP, PPV and NPV 
Table 3. Sensitivity, specificity, positive predictive value, negative predictive value and odd ratio of the different isotonic saline solution doses for 24-h SNa $\Delta \geq 8$ and $\geq 6 \mathrm{mmol} / \mathrm{L}$.

\begin{tabular}{|c|c|c|c|c|c|c|}
\hline & $\begin{array}{l}\text { Sensitivity } \\
\text { (95\% CI) }\end{array}$ & $\begin{array}{l}\text { Specificity } \\
(95 \% \text { CI })\end{array}$ & $\begin{array}{c}\text { Positive } \\
\text { Predictive } \\
\text { Value }(95 \% \mathrm{CI})\end{array}$ & $\begin{array}{c}\text { Negative } \\
\text { Predictive } \\
\text { Value }(95 \% \mathrm{CI})\end{array}$ & $\begin{array}{l}\text { Odd Ratio } \\
(95 \% \text { CI }) *\end{array}$ & $p^{*}$ \\
\hline \multicolumn{7}{|l|}{$\begin{array}{c}\text { SNa } \Delta \geq 8 \\
\text { Isotonic saline dose: }\end{array}$} \\
\hline$\geq 30 \mathrm{~mL} / \mathrm{kg} / 24 \mathrm{~h}$ & $80 \%(50-100)$ & $80 \%(60-100)$ & $67 \%(36-98)$ & $89 \%(72-100)$ & $16(2.5-95.1)$ & 0.004 * \\
\hline$\geq 22 \mathrm{~mL} / \mathrm{kg} / 24 \mathrm{~h}$ & $\begin{array}{c}100 \% \\
(95-100)\end{array}$ & $45 \%(21-69)$ & $48 \%(24-71)$ & $100 \%(94-100)$ & 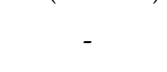 & - \\
\hline \multicolumn{7}{|l|}{$\begin{array}{c}\mathrm{SNa} \Delta \geq 6 \\
\text { Isotonic saline dose: }\end{array}$} \\
\hline$\geq 29 \mathrm{~mL} / \mathrm{kg} / 24 \mathrm{~h}$ & $67 \%(39-94)$ & $80 \%(55-100)$ & $77 \%(50-100)$ & $71 \%(46-95)$ & $13(2.2-72.1)$ & 0.007 * \\
\hline$\geq 22 \mathrm{~mL} / \mathrm{kg} / 24 \mathrm{~h}$ & $\begin{array}{c}100 \% \\
(97-100)\end{array}$ & $60 \%(32-88)$ & $71.4 \%(50-93)$ & $100 \%(94-100)$ & - & - \\
\hline $\begin{array}{c}\mathrm{SNa} \Delta \geq 6^{* *} \\
\text { Isotonic saline dose: } \\
\geq 29 \mathrm{~mL} / \mathrm{kg} / 24 \mathrm{~h}\end{array}$ & $73 \%(42-100)$ & $75 \%(46-100)$ & $73 \%(42-100)$ & $75 \%(46-100)$ & $8(1.2-51.5)$ & 0.029 * \\
\hline
\end{tabular}

Multivariate logistic regression analysis using forward Wald's step method permitted determination of ORs for different ISSDs, in relation with the 24-h SNa increment, according to the cut-off points derived from the ROC curves, as given in Table 3. Based on these results, the ISSDs that permit reaching the goal of correction of SNa stipulated in our study are between $23-30 \mathrm{~mL} / \mathrm{kg} / 24 \mathrm{~h}$.

\section{Discussion}

The current study has found that, in patients with $\mathrm{HH}$, the 24SNa increment is directly related to the ISSD employed for therapy. This was the case both for the entire group of patients studied, as well as for those with at least one risk factor for the development of ODS.

Clinical guidelines and expert opinions recommend the administration of isotonic saline $/ \mathrm{NaCl}$ $0.9 \%$ for the treatment of patients with $\mathrm{HH}$, while indicating the need for close follow-up, to avoid overcorrection of serum sodium levels $[1-3,19,22]$. However, the ISSD necessary to induce an adequate elevation of SNa levels without provoking overcorrection is unknown. Sahay M. and Sahay R. [3] suggest a $\mathrm{NaCl} 0.9 \%$ dose of $0.5-1 \mathrm{~mL} / \mathrm{kg} / \mathrm{h}$, without specifying the duration of therapy, nor the probability of therapeutic success or overcorrection. Based on the results of the current study, the dose recommended by Sahay M. and Sahay R., when administered over a 24-h period to a subject weighing $70 \mathrm{~kg}(14-24 \mathrm{~mL} / \mathrm{kg} / 24 \mathrm{~h}$ ), would have a low risk for overcorrection. However, there would be a high risk for undercorrection, since in our study, eight of nine patients receiving a similar dose ( $\leq 23 \mathrm{~mL} / \mathrm{kg} / 24 \mathrm{~h})$ did not attain the minimum therapeutic goal of a $4 \mathrm{mmol} / \mathrm{L} 24 \mathrm{SNa}$ rise [2,22].

Among measures proposed to avoid overcorrection during ISS administration are the measurement of SNa every $4-6 \mathrm{~h}$ as well as the monitoring of diuresis [1,2,23]. Desmopressin administration can also be associated $[9,14,24-26]$. However, in some hospital settings, all or parts of these recommendations could be difficult to apply. Therefore, if the mainstay of therapy of $\mathrm{HH}$ is ISS administration, an estimation of a dose with a high probability of achieving the stated goals is desirable. We have found that an infusion rate between $23-30 \mathrm{~mL} / \mathrm{kg} / 24 \mathrm{~h}$ of ISS would comply with these requisites.

Although a younger age [10,27], female sex [10], a low weight [10,28], malnutrition [9], hypokalemia as well as its treatment with $\mathrm{KCl}[2,9,17,29]$, and a lower baseline $\mathrm{SNa}[10,14,28]$ have all been associated with an increased risk for overcorrection, the current study has only found a significant association between a low baseline $\mathrm{SNa}$ and a 24-h SNa $\Delta \geq 8$, with a tendency detected in the rest of variables analyzed. We cannot, however, rule out that some of these parameters would be associated with a significant $\mathrm{SNa}$ rise if our study population had been larger. In any event, our findings suggest that the principal determinant of the 24-h SNa rise is the dose of ISS itself. 
The main limitation of this research is the small number of cases studied. An additional limitation is its retrospective methodology.

A strong point of the current study is the correct volemic classification of patients, based on various parameters that adhere to current scientific evidence $[2,16,19,20]$. Without a correct diagnosis of hypovolemia, its therapy simply cannot be evaluated $[2,9,17,18,30]$. Furthermore, essential clinical information, such as recent patient weight and the SNa level precisely $24 \mathrm{~h}$ after the start of ISS therapy, were available in all cases. The direct clinical relevance of the results is an additional strong point.

In conclusion, the ISS dose is directly related to the 24-h SNa rise following initiation of infusion. Based on our results, we recommend an ISS dose of 23 to $30 \mathrm{~mL} / \mathrm{kg} / 24 \mathrm{~h}$ to achieve an increase in SNa between $4-7 \mathrm{mmol} / \mathrm{L}$ over the first $24 \mathrm{~h}$ of therapy in patients with $\mathrm{HH}$. Further prospective studies with a larger number of patients should be undertaken to confirm these results.

Author Contributions: Conceptualization: J.G.R.-S.; methodology: J.G.R.-S., D.M., M.C.; validation: J.G.R.-S., D.M., M.C., C.Á.-E., A.L.C.-P., I.R.; formal analysis: J.G.R.-S., D.M., M.C.; investigation: J.G.R.-S.; writing-original draft preparation: J.G.R.-S., I.R.; writing—review and editing: J.G.R.-S., I.R., D.M., M.C., C.Á.-E., A.L.C.-P.; supervision and reviewing: D.M., M.C., C.Á.-E., A.L.C.-P., I.R. All authors have read and agreed to the published version of the manuscript.

Funding: J.G.R.-S. has a contract as a researcher with the Foundation for Biomedical Research at the Hospital Clínico San Carlos (Reference number: INV-15-2019), but this research received no external funding.

Acknowledgments: We thank Yvonne Fernández, Beatriz De León, Juan José Salazar and all the specialists of the endocrinology department of the Hospital La Paz, for their interest and support in the development of this research. The authors would like to thank Beatriz Runkle for her help in reviewing the manuscript.

Conflicts of Interest: The authors declare that they have no conflicts of interest.

\section{References}

1. Spasovski, G.; Vanholder, R.; Allolio, B.; Annane, D.; Ball, S.; Bichet, D.; Decaux, G.; Fenske, W.; Hoorn, E.J.; Ichai, C.; et al. Clinical practice guideline on diagnosis and treatment of hyponatraemia. Nephrol. Dial. Transplant. 2014, 29, i1-i39. [CrossRef]

2. Verbalis, J.G.; Goldsmith, S.R.; Greenberg, A.; Korzelius, C.; Schrier, R.W.; Sterns, R.H.; Thompson, C.J. Diagnosis, evaluation, and treatment of hyponatremia: Expert panel recommendations. Am. J. Med. 2013, 126, S1-S42. [CrossRef] [PubMed]

3. Sahay, M.; Sahay, R. Hyponatremia: A practical approach. Indian J. Endocrinol. Metab. 2014, $18,760$. [CrossRef]

4. Baylis, P.H. Posterior pituitary function in health and disease. Clin. Endocrinol. Metab. 1983, 12, 747-770. [CrossRef]

5. Norsk, P. Influence of low- and high-pressure baroreflexes on vasopressin release in humans. Acta Endocrinol. (Copenh) 1989, 121, 3-27. [CrossRef] [PubMed]

6. Yao, S.T.; Antunes, V.R.; Bradley, P.M.J.; Kasparov, S.; Ueta, Y.; Paton, J.F.R.; Murphy, D. Temporal profile of arginine vasopressin release from the neurohypophysis in response to hypertonic saline and hypotension measured using a fluorescent fusion protein. J. Neurosci. Methods 2011, 201, 191-195. [CrossRef] [PubMed]

7. NICE Guidelines. Intravenous Fluid Therapy in Children and Young People in Hospital; National Institute for Health and Care Excellence: London, UK, 2015.

8. Green, J.; Lillie, J. Intravenous fluid therapy in children and young people in hospital N29. Arch. Dis. Child. Educ. Pract. Ed. 2017, 102, 327-331. [CrossRef] [PubMed]

9. Gharaibeh, K.A.; Brewer, J.M.; Agarwal, M.; Fülöp, T. Risk factors, complication and measures to prevent or reverse catastrophic sodium overcorrection in chronic hyponatremia. Am. J. Med. Sci. 2015, 349, 170-175. [CrossRef] [PubMed]

10. George, J.C.; Zafar, W.; Dan Bucaloiu, I.; Chang, A.R. Risk factors and outcomes of rapid correction of severe hyponatremia. Clin. J. Am. Soc. Nephrol. 2018, 13, 984-992. [CrossRef] [PubMed]

11. Tanneau, R.S.; Henry, A.; Rouhart, F.; Bourbigot, B.; Garo, B.; Mocquard, Y.; Goas, J.Y. High incidence of neurologic complications following rapid correction of severe hyponatremia in polydipsic patients. J. Clin. Psychiatry 1994, 55, 349-354. 
12. Sterns, R.H.; Riggs, J.E.; Schochet, S.S. Osmotic Demyelination Syndrome Following Correction of Hyponatremia. N. Engl. J. Med. 1986, 314, 1535-1542. [CrossRef] [PubMed]

13. Sterns, R.H.; Cappuccio, J.D.; Silver, S.M.; Cohen, E.P. Neurologic sequelae after treatment of severe hyponatremia: A multicenter perspective. J. Am. Soc. Nephrol. 1994, 4, 1522-1530. [PubMed]

14. Aratani, S.; Hara, M.; Nagahama, M.; Taki, F.; Futatsuyama, M.; Tsuruoka, S.; Komatsu, Y. A low initial serum sodium level is associated with an increased risk of overcorrection in patients with chronic profound hyponatremia: A retrospective cohort analysis. BMC Nephrol. 2017, 18, 316. [CrossRef]

15. Hillier, T.A.; Abbott, R.D.; Barrett, E.J. Hyponatremia: Evaluating the correction factor for hyperglycemia. Am. J. Med. 1999, 106, 399-403. [CrossRef]

16. Tzoulis, P.; Runkle-De la Vega, I. The Diagnostic Approach to the Patient with Hyponatremia: Are the Correct Investigations Being Done? In Frontiers of Hormone Research. Disorders of Fluid and Electrolyte Metabolism. Focus on Hyponatremia; Peri, A., Thompson, C.J., Verbalis, J.G., Eds.; KARGER: Berlin, Germany, 2019; pp. 190-199.

17. Hoorn, E.J.; Zietse, R. Diagnosis and treatment of hyponatremia: Compilation of the guidelines. J. Am. Soc. Nephrol. 2017, 28, 1340-1349. [CrossRef]

18. Chung, H.-M.; Kluge, R.; Schrier, R.W.; Anderson, R.J. Clinical assessment of extracellular fluid volume in hyponatremia. Am. J. Med. 1987, 83, 905-908. [CrossRef]

19. Runkle, I.; Gomez-Hoyos, E.; Cuesta-Hernández, M.; Chafer-Vilaplana, J.; de Miguel, P. Hyponatraemia in older patients: A clinical and practical approach. Rev. Clin. Gerontol. 2015, 25, 31-52. [CrossRef]

20. Ruiz Sanchez, J.G.; Cárdenas Salas, J.; López Nevado, C.; Durán Rodriguez-Hervada, A.; Cuesta Hernández, M.; Calle Pascual, A.; Runkle de La vega, I. Nuevo Método Bioquímico Para la Clasificación Volémica de la Hiponatremia; Madrid, Spain. Endocrinol. Diabetes Nutr. 2019, 66, 7. [CrossRef]

21. Vu, T.; Wong, R.; Hamblin, P.S.; Zajac, J.; Grossmann, M. Patients Presenting with Severe Hypotonic Hyponatremia: Etiological Factors, Assessment, and Outcomes. Hosp. Pract. 2009, 37, 128-136. [CrossRef]

22. Peri, A.; Thompson, C.J.; Verbalis, J.G. (Eds.) Disorders of Fluid and Electrolyte Metabolism; Frontiers of Hormone Research; S. Karger AG: Berlin, Germany, 2019; Volume 52, ISBN 978-3-318-06382-0.

23. Pirzada, N.A.; Ali, I.I. Central pontine myelinolysis. Mayo Clin. Proc. 2001, 76, 559-562. [CrossRef]

24. MacMillan, T.E.; Cavalcanti, R.B. Outcomes in Severe Hyponatremia Treated With and Without Desmopressin. Am. J. Med. 2018, 131, 317. [CrossRef] [PubMed]

25. Ward, F.L.; Tobe, S.W.; Naimark, D.M.J. The Role of Desmopressin in the Management of Severe, Hypovolemic Hyponatremia: A Single-Center, Comparative Analysis. Can. J. Kidney Heal. Dis. 2018, 5, 2054358118761051. [CrossRef] [PubMed]

26. Garrahy, A.; Dineen, R.; Hannon, A.M.; Cuesta, M.; Tormey, W.; Sherlock, M.; Thompson, C.J. Continuous Versus Bolus Infusion of Hypertonic Saline in the Treatment of Symptomatic Hyponatremia Caused by SIAD. J. Clin. Endocrinol. Metab. 2019, 104, 3595-3602. [CrossRef] [PubMed]

27. Thorpe, O.; Cuesta, M.; Tormey, W.T.; Sherlock, M.; Williams, D.J.; Thompson, C.J.; Garrahy, A. 109 Hyponatraemia in Older Patients is Often Untreated, Despite Greater Mortality Burden; Results of A Prospective Cohort Study. Age Ageing 2020, 49, i34-i36. [CrossRef]

28. Kim, Y.; Lee, N.; Lee, K.E.; Gwak, H.S. Risk factors for sodium overcorrection in non-hypovolemic hyponatremia patients treated with tolvaptan. Eur. J. Clin. Pharmacol. 2020. [CrossRef]

29. Sterns, R.H. Disorders of Plasma Sodium-Causes, Consequences, and Correction. N. Engl. J. Med. 2015, 372, 55-65. [CrossRef]

30. Adrogué, H.J.; Madias, N.E. Hyponatremia. N. Engl. J. Med. 2000, 342, 1581-1589. [CrossRef]

Publisher's Note: MDPI stays neutral with regard to jurisdictional claims in published maps and institutional affiliations.

(C) 2020 by the authors. Licensee MDPI, Basel, Switzerland. This article is an open access article distributed under the terms and conditions of the Creative Commons Attribution (CC BY) license (http://creativecommons.org/licenses/by/4.0/). 